\title{
What Drives Religious Politicking? An Analysis of 24 Democratic Elections
}

\section{Emma Rosenberg}

University of Notre Dame

\section{Amy Erica Smith (D) \\ lowa State University}

\begin{abstract}
Why do clergy talk with congregants about elections to a greater extent in Mozambique than Indonesia, or in the United States than Taiwan? Arguing that context shapes religious actors' micro-level incentives to discuss or avoid electoral politics, we seek to explain variation in religious politickingreligious leaders' and organizations' engagement in electoral campaigns. Our framework integrates individual-level and country-level approaches, as well as theories of modernization, secularism, and religious competition. Drawing on survey data from 24 elections in 18 democracies in the Comparative National Elections Project, we find that human development depresses religious politicking, while secularism and religious pluralism boost it. However, "civilizational" differences in levels of religious politicking are muted and inconsistent. Finally, at the individual level, across the globe, citizens with higher levels of education are consistently more likely to receive political messages. Our results suggest the insights obtained from an approach emphasizing individuals embedded in contexts.
\end{abstract}

Why do clergy preach more about elections in some countries than in others? Why do religious associations contact members about upcoming elections more frequently in Mozambique than in Indonesia, or in the United States than in Taiwan? This paper investigates the sources of variation in "religious politicking"- the direct engagement of clergy and religious associations in elections. While scholarship on religion and democracy was historically concerned with the role of the former in

Address correspondence and reprint requests to: Amy Erica Smith, Iowa State University, Ames, Iowa. E-mail: aesmith2@iastate.edu 
promoting or undermining the latter, researchers have begun to move beyond questions of compatibility for nuanced explorations of how the two interact (e.g., Stepan 2000; Fox 2006; Kuru 2009).

Religious politicking manifests in diverse ways in democracies. Sometimes, clergy directly endorse candidates, such as when the Reverend Jesse Jackson told reporters in 2007 that presidential candidate Barack Obama "has my vote" (Clark 2007). Other endorsements are more subtle, such as when the Indonesian imam Abdullah Gymnastar counseled his congregation against voting for a non-Muslim during a Jakarta gubernatorial campaign involving a prominent Christian candidate, Ahok; or when U.S. evangelical pastor Gus Booth told his congregation, "if you are a Christian, you cannot support a candidate like Barack Obama or Hillary Clinton for president" (Goldman 2008; Emont 2017). Further, democracies vary significantly in the extent of religious politicking. In some, such as Mozambique and Brazil, it is commonplace for religious leaders to endorse politicians, or even run for office; in others, such as Argentina, religious endorsements are practically unheard of.

We contribute to the study of religious engagement in democratic elections, using data from 24 surveys in 18 democracies included in the Comparative National Elections Project (CNEP) between 1993 and 2012. Respondents were asked about two aspects of religious politicking: exposure to political messages from religious associations and from clergy, respectively.

Exploring the conditions under which religious actors take part in the electoral fray allows us to test several prevalent arguments in the literature on political behavior, modernization, and religious competition. First, at the individual level, we investigate the socioeconomic correlates of selfreported exposure to religious politicking, as well as whether there are consistent civilizational or theological differences across world religions. Second, we take up modernization theorists' claim that, at the country level, development, democracy, and legal secularism diminish the role of religion in public life-and revisionist theories maintaining, in contrast, that these three forces actually lead to rising levels of religious politicking. Third, we test claims within the religious competition literature that religious pluralism intensifies religious leaders' political engagement.

The CNEP provides a novel perspective on religious politicking. A large body of prior work examines religious politicking within single countries-an approach that yields richly detailed micro-level analysis, yet cannot fully assess the role of national context. Meanwhile, another body of work takes a state-centric perspective. Treating the state as the unit of analysis has obvious merit, in that the state naturally sets the 
parameters within which religious groups can interact with democracy, yet such analyses have tended to ignore citizens' own experiences of how their religious and political leaders interact. By utilizing cross-national data involving self-reports from citizens on the ground, we develop new measures of religious politicking that validly represent the observations of citizens themselves. At the same time, this approach enables us to integrate individual-level determinants of exposure to religious politicking into a state-level explanation of the phenomenon.

Our results shed new light on religious groups' insertion into electoral politics. On the one hand, they indicate that exposure to religious politicking is, in at least one important way, similar to other forms of political mobilization. In particular, education consistently increases the probability of exposure to religious elites' political messages, in a wide variety of national contexts-likely due to a combination of self-selection and deliberate targeting by elites. On the other hand, our results suggest that civilizational approaches-especially the ones emphasizing differences between Christians and Muslims-overstate group-level differences.

The results also illuminate the country-level correlates of religious politicking, supporting some aspects of modernization and religious competition theories, yet contradicting others. We find a strong negative relationship between human development and religious politicking across the democracies we study, despite the United States' status as an influential outlier with high levels of both human development and religious politicking. Yet both legal secularism (i.e., the formal separation of state from religious authority) and religious pluralism boost religious politicking. In other words, in societies with unregulated and competitive religious marketplaces, religious institutions participate more actively in the electoral fray. Thus, the results confirm the value of unpacking secularization theory.

\section{THE VARYING ROLES OF RELIGIOUS ENGAGEMENT IN DEMOCRATIC ELECTIONS GLOBALLY}

In the build-up to Mozambique's 2004 presidential elections, leading religious organizations - the Christian Council, Islamic Council, and Catholic Bishops' Conference- joined with civil society groups to form an electoral observatory (Cruz y Silva 2008, da Silva 2015. Their concerns were borne out when the election was marred by allegations of misconduct and the losing party, Renamo, initially refused to recognize Frelimo's victory (Manning 2010. Yet religious groups were not simply neutral 
observers. The Comparative National Election Survey that year found that more than one in 10 respondents reported a religious leader seeking votes for a candidate or party during religious services; a similar number said they received campaign literature from a religious organization (CNEP Mozambique 2004). The prominence of religious engagement is particularly striking, given that the campaign ostensibly had little to do with religion and religion is largely uncorrelated with partisanship in Mozambique (Pereira 2008).

In Indonesia's presidential election that same year, clergy behaved differently from counterparts on the other side of the Indian Ocean. Following Suharto's 1998 overthrow, the country's two dominant religious organizations, Nahdlatul Ulama (NU) and Muhammadiyah, had formed political parties (Lussier and Fish 2012, 78). Yet despite these groups' heavy engagement in politics and the fact that nearly $90 \%$ of Indonesians are Muslim, overtly Islamic candidates and parties underperformed-achieving just $36 \%$ of the vote in $1999,41 \%$ in 2004, and $29 \%$ in 2009 (Tanuwidjaja 2010). In 2009, the candidate endorsed by both NU and Muhamadiyah ended up with only $11 \%$ of the vote (Fealy and Bush 2014, 548), while survey experiments in 2012 and 2013 found that "political religiosity" reduced candidate support (Sumaktoyo, Ottati, and Untoro 2016, 481). Although some observers noted that declining support for Islamic parties masked increasing religious influence over secular and nationalist parties (Tanuwidjaja 2010, 44), the Comparative National Election Survey also confirmed the anemic religious engagement. Just $7 \%$ of Indonesians received campaign literature from a religious organization in 2005; by the 2009 election, this had dropped to 3\% (CNEP Indonesia 2004 and 2009).

Religious groups were yet less engaged in Argentina's 2007 presidential campaign. By some standards, the conditions were ripe for religious intervention. Abortion and same-sex marriage-two issues driving religious mobilization elsewhere in Latin America (Smith 2019)—were on the agenda. While the front-runner Cristina Fernández de Kirchner took relatively centrist stances on balance opposing abortion and supporting samesex marriage, candidates to her right took religiously framed and highly conservative approaches strongly opposing both (Sued 2007). Yet the religiously dominant Argentine Catholic Church, which had long advocated on those two issues in the halls of Congress (Esquivel 2016; Pecheny, Jones, and Ariza 2016), said little during the campaign: fewer than $1 \%$ of respondents reported clergy endorsing a candidate or party during services (CNEP Argentina 2007). 
These cases suggest two puzzles. First, what drives cross-national variation in religious leaders' and organizations' engagement in political campaigns? Second, why do some citizens perceive and report clergy politicking, when perhaps even those on the neighboring prayer mats or pews fail to do so? One prominent approach that could partially answer both questions involves "civilizational" differences between religious cultures across countries, or between world religions within a country (e.g., Huntington 1993). Yet it is not clear from these examples that differences between Muslims and Christians, or Catholics and Protestants, can explain the variation in which we are interested. Other approaches would emphasize long-term human development or medium-term political factors: levels of democracy, religious repression, and secular political institutions. And a final approach would focus not on the state but on religious institutionsnamely, the degree of inter-group competition for membership. In the next section, we integrate these approaches within a soft cost-benefit framework.

\section{EXPLAINING RELIGIOUS POLITICKING}

We conceptualize religious politicking as a form of strategic communication: (a) a messenger (the clergy member or religious association) transmits a message about politics, and (b) a citizen receives it. To explain religious politicking, we assess the factors that influence both steps in the process. In the first step, clergy and religious associations implicitly or explicitly assess the costs and benefits of this form of communication. On the benefit side of the tally, many sincere religious and political objectives-from promoting environmental stewardship to stopping abortion-motivate religious messengers. Such objectives vary dramatically by religious tradition as well as local and national context. Yet religious institutional concerns also motivate political speech. Perceived religious restrictions fuel grievances against the state, while religious competition can trigger groups to seek access to policy tools and political allies.

Engaging in religious politicking also imposes wide-ranging costs on the message sender. Even in the most frictionless environments, religious politicking entails opportunity costs, as the clergy member or religious association devotes limited sermon time to his or her message. Yet there are other potential costs. First, citizens in some contexts may disapprove of religious messages, potentially affecting the religious group's attendance and membership levels. In politically divided congregations and polarized electoral environments, electoral messages risk alienating 
congregants who disagree. Religious politicking may also sometimes violate citizens' norms regarding the secular division of labor between religious and political elites. Second, religious traditions vary in their tolerance for clergy and other religious actors' engagement in electoral politics. For instance, particularly since the 1980s, the Roman Catholic Church has generally frowned on clergy engagement in elections; by contrast, Protestant churches have exhibited more widely varying stances on religious politicking. Third, religious politicking can run afoul of state actors. Our study is restricted to democracies, where the state guarantees free and fair elections. Nonetheless, some democracies do actively repress or seek to control religious groups' speech about politics. Moreover, even in states with high levels of religious liberty, religious engagement in politics can alienate allies in government.

In the second step, some citizens are more likely to receive religious messages about elections than others. Given the strategic and costly nature of religious politicking, clergy and religious associations target citizens perceived as most likely to respond favorably to their messages. And even absent strategic targeting, some citizens are more likely to be exposed to, comprehend, and remember the political messages they receive. Drawing on the preceding logic, the next sections discuss determinants of exposure to religious politicking operating at the individual, group, and country levels.

\section{Which Citizens?}

We expect that exposure to religious messages regarding politics will be distributed non-randomly within countries and religious communities. A large number of single-country case studies examines political cues from the clergy - yet there is surprisingly little prior research on which citizens are most likely to receive such messages. Our view of religious politicking as a system of strategic communication guides our reflection on which citizens are likely to receive such messages.

To the extent they can target their messages at all, we expect that strategic message senders will focus on recipients perceived as more persuasible and more likely to take action. This assumption leads to two predictions. The first seems almost too obvious to mention: clergy and religious associations will target members of their own groups and particularly highly engaged ones. Such targeting is analogous to clientelistic brokers' preference for mobilizing individuals within their own parties (Stokes et al. 2013). This targeting could help to explain the cross-national 
association between religious attendance and political participation (Bolzendahl, Schnabel, and Sagi 2019). Second, religious leaders will focus on citizens with more education. Prior work confirms that many forms of mobilization target those with higher socioeconomic status and resources, both in the United States and cross-nationally (e.g., Verba, Nie, and Kim 1978; Brady, Verba, and Schlozman 1995). The bias towards mobilizing wealthier and better-educated citizens may well express mobilizers' prejudice or innate preference for those groups, but it is also strategic. Citizens with more resources-from cognitive resources to social capital, to time, to tools such as cars and Internet connectionsrespond more readily to calls to action. They also more readily in turn mobilize others.

Yet even when pastors, imams, or priests try to rally the faithful, they may fail to get their points across. Some citizens will simply be more aware of the political messages religious leaders send than others; that is, they will be more likely to register, comprehend, and remember what they hear. Zaller's (1992) "Receive-Accept-Sample (RAS)" model provides a helpful framework for thinking about the determinants of effectively receiving political communications from opinion leaders. Conveniently, the predictions from this approach dovetail with those from the prior paragraph: more frequent attenders and those with higher levels of education should be more aware of religious leaders' political stances. Thus, we hypothesize that:

Hypothesis 1: Across country contexts, more highly educated citizens and citizens who attend services more frequently will be more likely to report exposure to religious politicking.

Still, it is worth mentioning that the opposite relationship is possible: education could instead decrease exposure to religious politicking. As prior research shows, human development is negatively associated with religiosity - a relationship we confirm in our data at the individual and country levels. Yet even if the poor are over-represented in the pews, we expect that wealthy and well-educated citizens in their midst will be most likely to receive, register, and report religious politicking.

\section{Which Religious Groups?}

Beyond individual-level studies, so-called "civilizational" approaches provide perhaps the most common explanation of religious politicking: 
that something about certain religious groups makes them more politically engaged. Proponents focus on the different world religions or branches of the Christian tree, arguing that groups' widely varying levels of political engagement result from inherent traits (Huntington 1993). Thus, the argument goes, doctrine and traditions of scriptural interpretation lead evangelical and Muslim leaders worldwide to engage more frequently in politicking than leaders of other groups. Such interpretations may not be inherent in holy religious texts themselves, yet within religious traditions, interpretive communities diffuse common understandings of holy texts. If "civilizational" approaches explain levels of religious engagement in politics, we hypothesize that:

Hypothesis 2: Across country contexts, evangelicals and Muslims will be more likely to report exposure to religious politicking.

Critics argue that civilizational approaches fail in two ways, however (Kuru 2009). First, such explanations dramatically under-predict variance in the behavior of actors within a religious tradition-for instance, the differences between Muslim leaders in Mozambique or Indonesia. Second, they over-predict variance between actors from different traditions-for instance, Christian versus Muslim leaders in Mozambique's 2004 election. As Dowd argues, a religious actor's social context shapes his or her political behavior more strongly than does the religious tradition: "there is something about certain times and places that prompts people, regardless of faith tradition or denomination, to apply their religious traditions to politics" (Dowd 2015, 2).

\section{Which Countries?}

Thus, we examine the role of context. What aspects of time and place matter? Secularization theory (sometimes called modernization theory in this literature) provides a starting point for an integrated explanation. Based heavily on European case studies, scholars argue that modernization produces secularization - that is, that religion's public role declines organically over time as development and democracy rise, and as democratic states adopt secular constitutional frameworks (Huntington 1968; Berger 1979; 1967; Bruce 2002; Norris and Inglehart 2011). However, the reality of enormous cross-national variation in religious engagement in public life has led to a vast literature debating both the theory's accuracy, as well as the mechanisms that could explain a modernization- 
secularization link (e.g., Stark 1999; Toft, Philpott, and Shah 2011; Gaskins, Golder, and Siegel 2013; Karakoç and Başkan 2013).

We argue that grasping modernization's effect on the public role of religion requires unpacking the term. Different aspects of modernizationamong them human development, democracy, and secularism-could affect religious politicking differently. (While secularization refers to the declining public role of religion, secularism means a legal, constitutional framework in which the state is independent of and neutral toward religious institutions.) In addition, religious pluralism is an oftoverlooked consequence of modernization that we argue has downstream effects on religious politicking. We also argue that understanding religious politicking requires attention to the micro-level incentives of religious actors. Various aspects of modernization shape the costs and benefits of religious politicking. Thus, we both disaggregate the concept of modernization and integrate secularization theory with an actor-oriented approach. The subsections that follow address three contextual forces that could encourage or discourage religious groups and leaders from taking sides in electoral contests: development, regime characteristics, and religious pluralism.

\section{Human Development}

A core claim of secularization theory has been that economic growth and human development lead to declining religiosity, and to a declining role for religion in public life. This premise has been sharply attacked for its Western-centric focus, as scholars have noted that not all developed countries become more secular, while some poor states are highly secular (Chaves 1994; Fox 2006; Casanova 2011; Berger 2012). Nonetheless, recent cross-national studies reaffirm the negative relationship between development and religiosity (e.g., Bruce 2002; Norris and Inglehart 2011). Norris and Inglehart (2011) outline the individual-level mechanisms supposed to underlie this aggregate-level relationship. They argue that "existential insecurity" caused by poverty and instability intensifies religiosity: "the experiences of growing up in less secure societies will heighten the importance of religious values, while conversely experiences of more secure conditions will lessen it" (17).

Religiosity is not synonymous with religious politicking, of course. Higher religiosity in developing countries would not automatically trigger religious politicking; one can certainly attend religious services 
without exposure to political content. Nonetheless, we expect that low development will be linked to religious politicking. The relationship is partially mechanical, as highly religious people have more opportunities for such exposure. But high religiosity in a society also changes norms, fostering greater tolerance for-or even expectations of-religious groups' engagement in the public sphere. As a consequence, political leaders are more likely to deploy religious claims and mobilization strategies strategically (McCauley 2017). More generally, campaigns in developing countries rely heavily on word of mouth and on local opinion leaders, given low literacy rates and uneven reach of newspapers or even, in some settings, television (e.g., Conroy-Krutz 2016; Smith 2018). In such contexts, clergy and religious associations may play a more important role in informing and mobilizing citizens. Thus, we hypothesize that:

Hypothesis 3: At the country level, as human development rises, exposure to religious politicking will fall.

Nonetheless, recent work argues for more complex relationships. Gaskins, Golder, and Siegel (2013), for instance, claim that religious groups often become more publicly engaged even as religious adherence falls. ${ }^{1}$ In line with secularization theory, they postulate a "substitutability of secular and religious goods," leading to a negative correlation between development and religiosity (Gaskins, Golder, and Siegel 2013, 1126). Nonetheless, they claim that secularization does not necessarily lead to a decline in religious politicking:

Those who remain religious in the face of growing development are increasingly likely to be more conservative and differentiated in their social attitudes relative to the rest of society. This fact, combined with the decline in the overall size of the religious community ... may make it easier for religious individuals to overcome collective action problems and achieve disproportionate influence (1126).

Similarly, Fox (2006) argues that "it is precisely in those states where modernity has most undermined the traditional community that religious elements within the state are most likely to try and legislate religious morals and traditions that were previously enforced at the social level" (526). Following this line of reasoning, human development might boost religious politicking among the (shrinking) minority of citizens who attend religious services frequently — even as it depressed religiosity 
overall. Such an interactive relationship between religious attendance and human development would disconfirm our third hypothesis.

\section{Regime Characteristics}

Several regime characteristics-including democracy, state secularism, and repression of religion-may impact religious engagement in politics. Secularization theory bundled democracy, secularism, and decreased religiosity together in a syndrome of modernization, without a consensus on the direction of causality (Huntington 1968; Berger 1979). Once again, though, revisionist approaches argue that these forces do not necessarily evolve all together as modernization progresses. We concur with recent scholars: understanding the effect of regime characteristics requires more precise analysis of context (Philpott 2007; Toft, Philpott, and Shah 2011; Dowd 2015; Grzymala-Busse 2015).

Legal, formal secularism may affect religious leaders' incentives for religious politicking by increasing the potential benefits and lowering the costs. In contrast to the predictions of secularization theory, scholarship on "religious economies" suggests that secularism—framed as deregulation of the religious market-heightens religious activity in a polity (Finke and Iannaccone 1993). When the state is neutral, all religious groups may acquire grievances and incentives leading to religious politicking. Dominant religious groups may fight for market advantages, while minority and historically disadvantaged ones may struggle for a level playing field (Toft, Philpott, and Shah 2011; Karakoç and Başkan 2013; Smith 2019). Meanwhile, state neutrality also decreases the potential costs of religious politicking. Thus, we hypothesize that:

Hypothesis 4: Secularism increases religious politicking.

Religious repression, in turn, reflects de facto state practices toward religious groups. Repression could potentially either increase or decrease religious politicking (Koesel 2014; Grzymala-Busse 2015). It can intensify members' grievances, pushing clergy and religious organizations into political—often radical or extremist-activities (Stark and Finke 2000; Toft, Philpott, and Shah 2011). Yet it could also reduce religious engagement in electoral politics, even while boosting extremist political behavior. When religious repression raises the costs of engagement in electoral politics, actors may substitute more radical forms of engagement. 
Given these competing predictions, we do not develop hypotheses related to religious repression.

Does a country's level of democracy influence religious politicking? The literature once again yields mixed expectations. As noted above, democracy was thought to be part of the package of modernization that led to secularization. However, revisionist theories argue that democracy instead increases religious engagement in politics, by lowering its costs. For instance, Toft, Philpott, and Shah $(2011,49)$ maintain that the spread of global democracy has contributed to a historical juncture in which "major religious actors throughout the world enjoy greater capacity for political influence today than at any time in modern history-and perhaps ever."

Nonetheless, we suspect that this debate has been muddied by conflating democracy with other covarying regime characteristics. Empirically, democracy is positively correlated with secularism and negatively with religious repression. We suspect that many of the effects attributed to democracy are instead due to these two other characteristics. In addition, we need to keep in mind that democracy is strongly correlated with human development, which itself likely impacts religious politicking. Thus, theoretically and empirically identifying the effect of democracy requires also taking into account secularism, religious repression, and human development. After controlling for these three traits, and assuming a country holds contested elections (a minimum requirement for inclusion in our dataset), we see no reason to expect that levels of democracy as such affect religious politicking.

\section{Religious Pluralism}

Last, religious pluralism can be considered an oft-overlooked aspect of modernization. Peter Berger, an early proponent of secularization theory, later reconsidered the modernization-secularization link: "It turns out that modernity does not necessarily produce a decline of religion; it does necessarily produce ... a historically unprecedented situation in which more and more people live amid competing beliefs, values and lifestyle" (2012, 313).

How does pluralism affect religious politicking? Scholars of religious economies show that religious diversity fosters inter-group competition for everything from members, to resources such as real estate, to special legal recognition (Finke and Stark 1998; Gill 2008; Trejo 2012; Smith 
2019). Competition, combined with grievances stemming from perceived state bias or favoritism, shapes the costs and benefits of religious politicking. Sometimes religious actors ally themselves with parties to recruit and retain members, helping to explain religious-political coalitions in cases such as the United States and Brazil (Audette and Weaver 2016; Djupe and Neiheisel 2019; Smith 2019). Groups can also use electoral politics to seek allies in government, or to change a political system they perceive as treating them unfairly. Dowd argues that "as societies become more religiously diverse, leaders of growing religious minorities promote political activism to reduce the privileges of long-dominant religious majorities, and leaders of long-dominant religious majorities encourage political activism in an attempt to preserve cultural and religious hegemony" (2015, 44-45). We hypothesize:

Hypothesis 5: As religious pluralism rises, so will religious politicking.

Empirically, case studies hint that competition increases religious politicking (Iannaccone 1992; Finke and Iannaccone 1993; Gill 2008; Akdede 2010; Trejo 2012; Smith 2019). Trejo (2012), for instance, demonstrates that subnational competition between Catholics and evangelicals in Mexico led Catholic clergy to champion indigenous rights. Similarly, Gill (2008) and Smith (2019) find that Catholic-evangelical competition in Latin America shaped both groups' political stances. Ultimately, religious groups' electoral activism could have feedback effects on democracy itself (Akdede 2010).

\section{DATA}

We test these hypotheses using cross-national survey data from the CNEP, as well as election- and country-level data from a variety of sources. The CNEP is a collaborative endeavor involving 48 surveys of elections in 26 democracies throughout the world between 1990 and 2016. In 24 surveys in 18 countries between 1993 and 2012, respondents were asked about exposure to political messages from religious associations and clergy, respectively. The multi-level data enable us to explore both individual and state-level explanations of religious politicking.

We have two dependent variables. Clergy candidate support is an indicator coded " 1 " for those who responded in the affirmative to the question, "During religious ceremonies, did the religious leader tend to favor a particular political party or candidate?" This variable was measured in only 
seven surveys. The second dependent variable, religious association information, is derived from a battery of questions on associational membership included in 23 surveys. Individuals who reported belonging to a "religious association" were asked, "Did you receive some information about the last electoral campaign from this organization?"2 The indicator is coded " 1 " for individuals who said yes.

These two variables capture distinct aspects of the larger phenomenon. Clergy candidate support examines religious leaders' partisan behavior within the walls of their own communities - the type of political communication most commonly described as "religious politicking." However, staking out a partisan position can be relatively risky for religious leaders, and as such, it is perhaps unsurprising that this activity was not measured in many countries. By contrast, religious association information captures a wider range of political communication, ranging from providing ostensibly nonpartisan information on voting procedures and candidate stances to encouraging turnout. This latter variable also enables us to examine religious politicking in a larger set of countries and elections.

While the variables do capture different aspects of religious politicking, responses are closely related. In the six surveys including both variables, the election-level correlation between the two is 0.72 . Thus, in the Appendix and in some analyses within the text, we present results for a summary index of religious politicking, which is coded " 1 " for all individuals who report either form of exposure to political messages. The summary index of religious politicking is present in all 24 elections in our dataset-including in the United States 2004, which is the only election where religious association information is not measured.

Our sample has some obvious limitations. The 24 elections and 18 countries we study are not drawn from a random sample; instead, they were non-randomly selected by the principal investigators, undoubtedly partially on the basis of idiosyncratic criteria such as professional contacts. This could potentially lead to over-representation of cases that are politically salient, or that are better connected to Western research networks, with unclear implications for representativeness. Furthermore, since one criterion for inclusion is that a case be democratic, the sample underrepresents elections in majority Muslim countries.

Nonetheless, the CNEP incorporates a highly diverse set of countries across the globe, including rich and poor countries, and ones on every continent. This is by far the largest and most comprehensive dataset to incorporate measures of religious politicking of which we are aware. As 
such, despite the caveats, the CNEP enables unprecedented insight into religious engagement in elections worldwide. Moreover, we have every reason to believe that the selected elections are representative of their respective regions and period.

Another concern relates to the characteristics of the individual-level sample. The data rely on citizens' self-reports of clergy and religious association behavior, rather than more direct measures of religious politicking. Signals between religious leaders and faithful citizens inevitably decay. Some citizens may fail to notice or deliberately ignore political messages from religious actors; others may fail to report what they experience. Moreover, measurement error is likely to be heterogeneous across the population, with more attentive and sophisticated citizens exhibiting less reporting error. Thus, at the individual level, the dependent variable must be interpreted in terms of perceptions and self-reports.

Our election-level variables are reported in Table 1. To examine religious repression and democracy, we use Varieties of Democracy measures for Liberal Democracy and Repression of Religious Organizations (Coppedge et al. N.d.). Our indicator variable for secularism (referring to a formal, legal separation of state from religious institutions) is based on Kuru's (2009) State-Religion Regimes Index, which classifies regimes as "established" if they have an official religion such as the Catholic Church in Bolivia or the Orthodox Church in Greece, and "secular" if not. Human development relies on the United Nations Development Programme's Human Development Index (HDI) (Human Development Data, 19902015 , N.d.). ${ }^{3}$ Finally, religious pluralism is a measure of the effective number of religious groups in each election, estimated based on the distribution of the survey data. Each of these election-level variables is subsequently converted to run from 0 to 1 , based on observed values within the data.

Individual-level variables include religious affiliation, religiosity, age, gender, education, and income. In some electoral surveys, such as South Africa 2005 and 2009, the CNEP measured upwards of 30 religious affiliations. We collapsed Christian religious denominations into Catholic, Protestant, evangelical (including Pentecostal), and Orthodox. We collapsed all Muslim denominations into "Muslim," given a lack of diversity among Muslims within the countries studied. Respondents who indicated no religious denomination were coded as "None." Religiosity was based on questions within each country asking how frequently respondents attended religious or worship services. Responses within each country were rescaled to run from 0 to 1 , and respondents who replied that they did not know were coded as missing. ${ }^{4}$ Age is measured in numbers of years (rescaled from 0 to 1 ) 
Table 1. Election-level measures (on original scales)

\begin{tabular}{|c|c|c|c|c|c|}
\hline & Human Development Index & Secularism & Religious repression & Liberal democracy & Religious pluralism \\
\hline Chile 1993 & 0.713 & Secular & 3.02 & 5.56 & 1.686 \\
\hline Spain 1993 & 0.783 & Established (Catholic) & 3.21 & 4.87 & 1.389 \\
\hline Uruguay 1994 & 0.709 & Secular & 3.11 & 5.05 & 1.447 \\
\hline Bulgaria 1996 & 0.702 & Established (Orthodox) & 2.54 & 4.04 & 2.161 \\
\hline Greece 1996 & 0.777 & Established (Orthodox) & 3.17 & 3.69 & 1.000 \\
\hline Italy 1996 & 0.805 & Established (Catholic) & 2.98 & 4.23 & 1.603 \\
\hline Hong Kong 1998 & 0.816 & Secular & N/A & N/A & 2.283 \\
\hline Hungary 1998 & 0.754 & Secular & 2.81 & 5.01 & 2.736 \\
\hline Greece 2004 & 0.839 & Established (Orthodox) & 3.19 & 3.69 & 1.093 \\
\hline Indonesia 2004 & 0.629 & Secular & 2.08 & 4.38 & 1.264 \\
\hline Mozambique 2004 & 0.341 & Secular & 1.26 & 4.33 & 4.019 \\
\hline South Africa 2004 & 0.609 & Secular & 2.63 & 5.11 & 4.715 \\
\hline Spain 2004 & 0.837 & Established (Catholic) & 3.26 & 4.87 & 1.638 \\
\hline Taiwan 2004 & N/A & Secular & 2.73 & 4.76 & 3.422 \\
\hline Uruguay 2004 & 0.753 & Secular & 3.29 & 5.05 & 2.779 \\
\hline United States 2004 & 0.895 & Secular & 3.12 & 4.17 & 4.952 \\
\hline Portugal 2005 & 0.793 & Established (Catholic) & 3.25 & 5.7 & 1.334 \\
\hline Hungary 2006 & 0.809 & Secular & 2.69 & 5.01 & 2.514 \\
\hline Italy 2006 & 0.862 & Established (Catholic) & 2.99 & 4.23 & 1.170 \\
\hline Mexico 2006 & 0.731 & Secular & 2.12 & 4.37 & 1.980 \\
\hline Argentina 2007 & 0.792 & Established (Catholic) & 2.48 & 4.58 & 1.538 \\
\hline Indonesia 2009 & 0.656 & Secular & 1.94 & 3.12 & 1.261 \\
\hline South Africa 2009 & 0.630 & Secular & 2.57 & 5.11 & 3.541 \\
\hline Spain 2011 & 0.871 & Established (Catholic) & 3.28 & 4.87 & 1.598 \\
\hline Mexico 2012 & 0.753 & Secular & 2.01 & 4.37 & 1.556 \\
\hline
\end{tabular}


and gender as a dichotomous indicator coded "1" for women. Education and income are measured on country-specific scales, which are standardized to run from 0 to 1 within each country.

\section{RESULTS AND DISCUSSION}

To what extent do citizens in democracies around the world receive political messages from their religious organizations and clergy? Figure 1 presents the distribution of the two dependent variables. The seven cases in the top pane represent the elections where clergy candidate support was measured; the 23 cases in the bottom pane include every election in our data set except the 2004 U.S. election, where the variable in question was not asked. ${ }^{5}$

In the subset of surveys where both dependent variables were included, levels of religious politicking are fairly consistent using the two measures. Mozambique's 2004 election presents the highest levels of religious politicking; $11.0 \%$ of Mozambicans said that they had received electoral information from religious organizations, while $12.7 \%$ said their clergy had tended to favor a candidate. Meanwhile, levels of religious politicking are quite low on both measures in Portugal 2005, Taiwan 2004, Argentina 2007, and South Africa 2004. In South Africa's 2009 election, however, there is a sizable gap between results for the two dependent variables. Though $9.8 \%$ of South Africans reported receiving information from a religious association, only $3.3 \%$ said their clergy had favored someone.

Beyond this subset of six cases with overlap, the 2004 election in the United States stands out as being among those with the highest levels of religious politicking; $10.4 \%$ of Americans thought their clergy had supported a candidate in sermons. Indonesia's 2004 campaign also had fairly high religious engagement, with $7.8 \%$ of citizens reporting that they had received political information from a religious organization. Meanwhile, in the remaining cases, few citizens reported that their religious organizations promoted campaign information.

\section{Individual- and Group-Level Determinants of Exposure to Religious Politicking}

Which kinds of people are most likely to say they are exposed to religious politicking? In the Appendix, we present a series of hierarchical logistic regression models assessing individual-level determinants of the two 

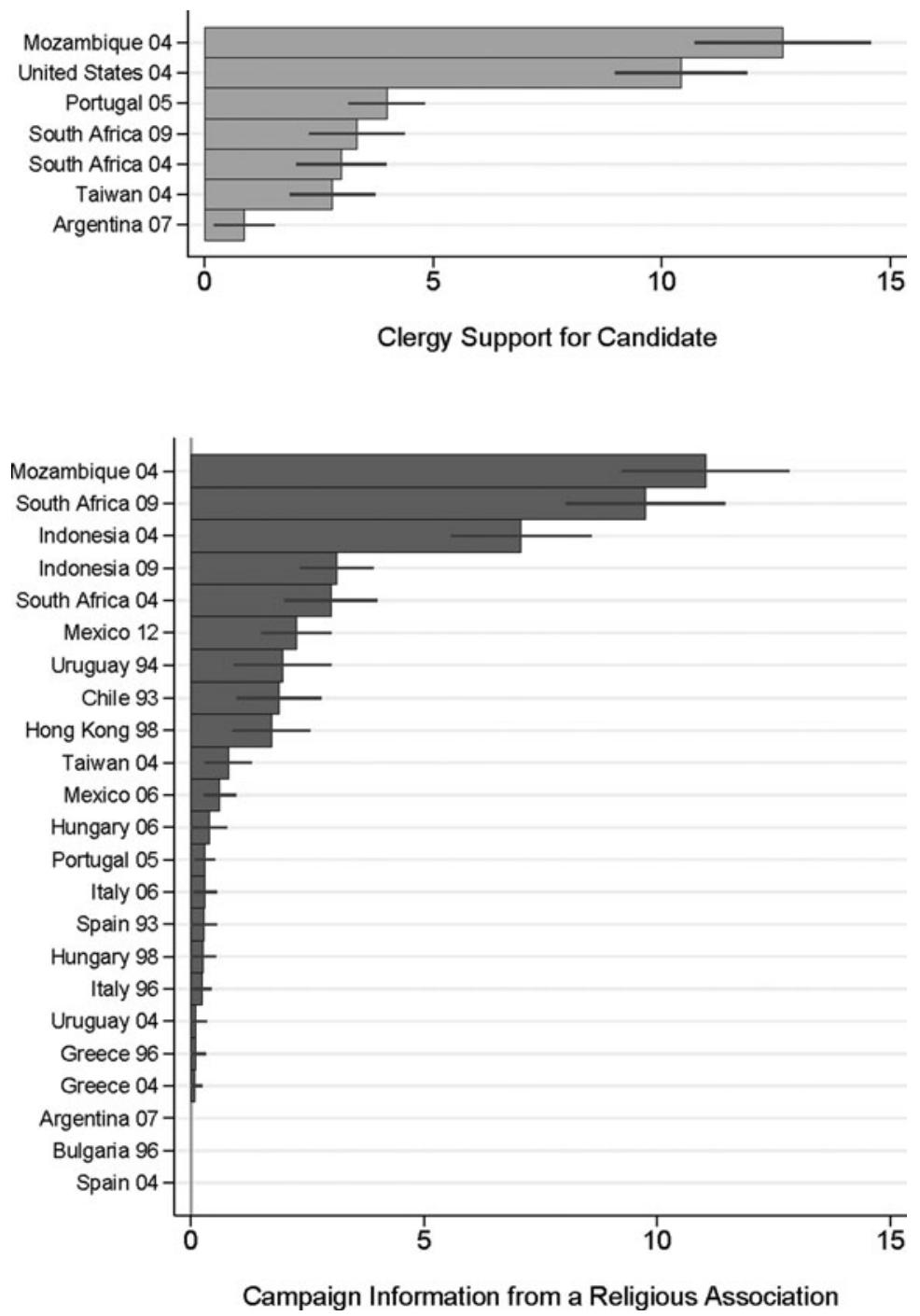

FIGURE 1. Levels of reported religious politicking, by country.

primary dependent variables, as well as of the summary index. Results strongly support our first hypothesis, that citizens who attend services more frequently and are more highly educated will be more likely to report exposure to religious politicking. Moving from the minimum to maximum levels of religious attendance is associated with more than a tripling of the likelihood of reporting any form of religious politicking. 


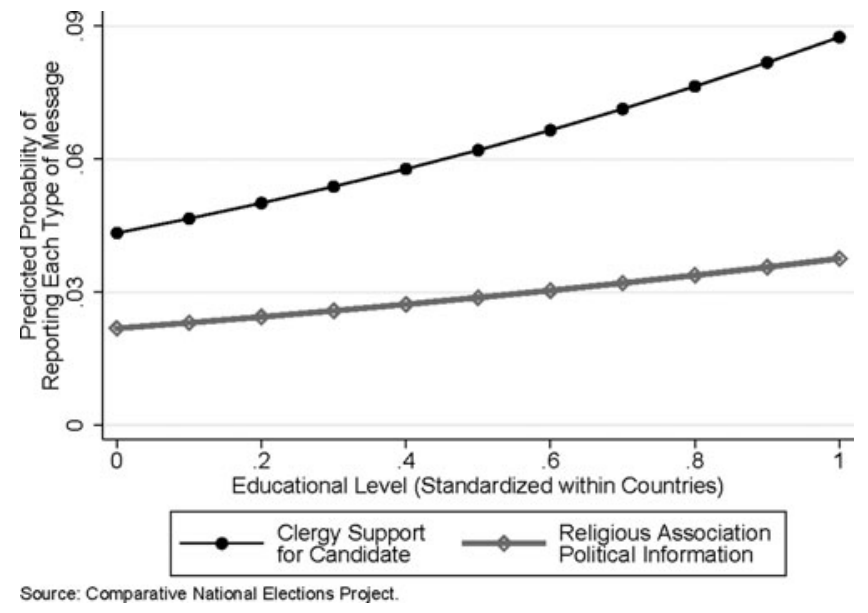

FIGURE 2. Levels of reported religious politicking, by educational level.

Less obvious is education's consistent positive effect on the likelihood of exposure to religious politicking. ${ }^{6}$ Figure 2 presents the predicted probabilities of an individual reporting political messages from clergy and religious associations, respectively, by educational level. Given the dramatic variation in educational systems across the countries studied, we standardize education to run from 0 to 1 within each country, so that it represents a measure of status relative to one's fellow citizens, but not relative to citizens in other countries. Evidently, people with more education are more likely to report exposure to both kinds of political messages. Moving from minimum to maximum levels of education is associated with a $69 \%$ increase in the likelihood of reporting any form of religious politicking, based on the summary index. In follow-up analysis (see the Appendix), we find that the impact of education on receiving political information from religious associations depends on religious attendance. Religious associations appear to narrowly target their outreach to people who are both highly religious and highly educated; highly educated but non-religious citizens do not receive outreach. By contrast, the impacts of education and religious attendance on exposure to political messages in clergy preaching appear to be independent.

Are some religious groups consistently more likely to engage in religious politicking? Figure 3 assesses the answer, based on the aforementioned models found in the Appendix. Though the regression models reveal some statistically significant differences between Catholics (our baseline 


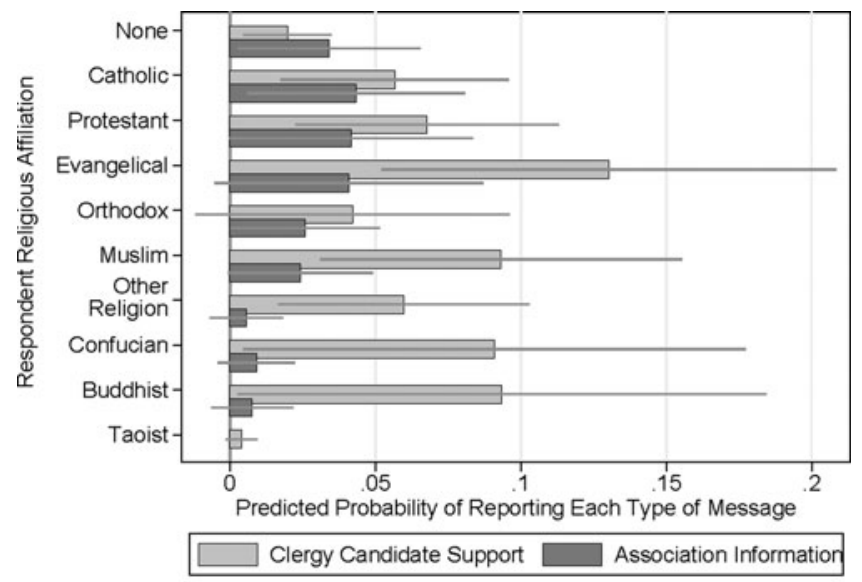

Source: Comparative Netional Elections Project. Whiskers represent 95\% confidence intervals

FIGURE 3. Levels of reported religious politicking, by religious affiliation.

group) and other religious groups, the figure provides only mixed support for the second hypothesis. Consistent with Hypothesis 2, evangelicals report greater clergy support for candidates-a finding echoed in models predicting the summary index. By contrast, Hypothesis 2 appears not to be supported with respect to Islam. Islam is associated with neither higher nor lower religious politicking than Catholicism-though Muslims are less likely than adherents to other major world religions to receive political messages from civic associations, and somewhat more likely than Catholics to have clergy who favor candidates.

Not surprisingly, the nonreligious report little exposure to religious politicking — an effect that holds even after controlling for frequency of religious attendance. Likewise, Confucians, Buddhists, and Taoists receive very little political information from religious associations, an effect largely explained by the groups' low frequency of religious attendance. The predicted rates of clergy support for candidates among Buddhists and Taoists are high, yet given small numbers of people in these samples, the $95 \%$ confidence intervals are very large and nearly incorporate 0 .

\section{Contextual Determinants of Religious Politicking}

Which aspects of context explain the greatly varying levels of religious politicking cross-nationally? We hypothesized that while secularism (Hypothesis 3) and religious pluralism (Hypothesis 5) would increase 

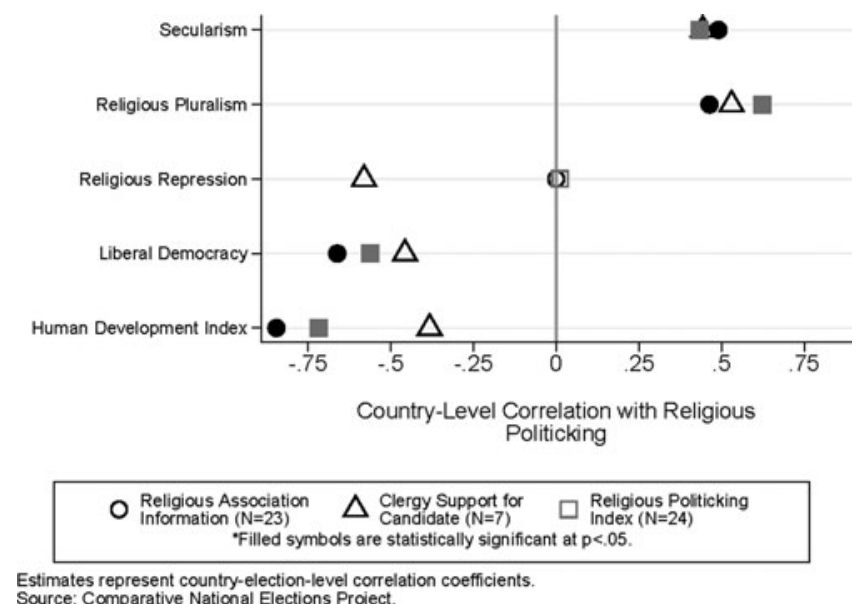
Source: Comparative National Elections Project.

FIGURE 4. Religious politicking and country-level explanatory factors.

religious politicking, human development would decrease it (Hypothesis 4). We did not specify hypotheses for democracy or religious repression. In Figure 4 we present the bivariate correlations between our five electionlevel variables, on the one hand, and the two primary dependent variables as well as the summary index of religious politicking, on the other. ${ }^{7}$ Data have been aggregated at the country-election level, so that values represent the mean within each case. Circles represent the Pearson correlation coefficients between the mean level of religious association information and each potential explanatory variable. Meanwhile, triangles and squares represent the equivalent correlations between the independent variables and the mean levels of clergy candidate support and the religious politicking index, respectively. Hollow symbols represent coefficients that fail to meet a $p<0.05$ level of statistical significance, while filled symbols represent coefficients that are statistically significant at this level.

For four of the five contextual variables, we find substantial consistency in results across the three dependent variables. Figure 4 displays sizable negative correlations between religious politicking and liberal democracy and human development, and sizable positive ones between the dependent variables and secularism and religious pluralism. By contrast, results vary for religious repression-yet on the whole it appears that the correlation between religious repression and religious politicking may be nearly exactly zero. With only seven cases, none of the correlations involving 
clergy support for candidates are statistically significant. However, the other two dependent variables are significantly related to human development, liberal democracy, secularism, and religious pluralism.

Table 2 presents results from hierarchical logistic regression models regressing the indicator for religious association information on the election-level variables, controlling for individuals' religious affiliation. ${ }^{8}$ (Given the small number of elections, we cannot estimate multi-level models using clergy support for candidates as the dependent variable; a similar table using the index of religious politicking as the dependent variable is presented in the Appendix.) The table presents only the coefficients for the second-level variables; full results are presented in the Appendix. The first five columns introduce each second-level variable individually, and confirm the results from the bivariate correlations at the election-level: liberal democracy and human development decrease exposure to religious group political messages, while, as we predicted, secularism and religious pluralism increase it.

The final column of Table 2 introduces all five second-level independent variables together. The results appear to indicate that, as we had expected, liberal democracy is not significantly associated with religious politicking, once human development is controlled. In addition, religious pluralism becomes statistically insignificant controlling for secularism. ${ }^{9}$ However, given the relatively low number of second-level cases, the results in that column should be taken with some caution. The reversed sign on the coefficient for religious pluralism is likely a result of high multicollinearity among the variables in this small set of cases. ${ }^{10}$ In the Appendix, we estimate two election-level models regressing the election-level means of religious politicking and religious association information on all five second-level independent variables. The results should, once again, be interpreted with caution because of the small number of cases. Still, in these multivariate models, the only statistically significant determinants of religious engagement in politics are human development and religious pluralism. Taken as a whole, the results suggest that low human development, secularism, and religious pluralism all encourage religious leaders and groups to take part in electoral campaigns.

Finally, we pause to consider more deeply the effect of human development. Earlier, we discussed a plausible alternative to Hypothesis 3: perhaps human development raises exposure to religious politicking among the devout, as highly religiously engaged citizens reject the secularizing impact of development (Fox 2006; Gaskins, Golder, and Siegel 
Table 2. Contextual determinants of receiving political information from religious associations

\begin{tabular}{|c|c|c|c|c|c|c|}
\hline & (1) & (2) & (3) & (4) & (5) & (6) \\
\hline Liberal democracy & $\begin{array}{c}-4.281 * * \\
(1.291)\end{array}$ & & & & & $\begin{array}{c}-0.910 \\
(1.635)\end{array}$ \\
\hline Human development index & & $\begin{array}{c}-6.066^{* *} \\
(1.598)\end{array}$ & & & & $\begin{array}{c}-5.556 * * \\
(2.002)\end{array}$ \\
\hline Religious repression & & & $\begin{array}{c}1.420 \\
(1.837)\end{array}$ & & & $\begin{array}{c}1.996 \\
(1.316)\end{array}$ \\
\hline Secularism & & & & $\begin{array}{l}2.965 * * \\
(0.659)\end{array}$ & & $\begin{array}{l}1.629 * * \\
(0.632)\end{array}$ \\
\hline Religious pluralism & & & & & $\begin{array}{c}3.217^{*} \\
(1.522)\end{array}$ & $\begin{array}{c}-2.324 \\
(1.217)\end{array}$ \\
\hline Observations & 32,319 & 32,050 & 32,319 & 32,319 & 33,305 & 31,070 \\
\hline Countries & 22 & 22 & 22 & 22 & 23 & 21 \\
\hline
\end{tabular}

Note: Results from multilevel logistic regression models. Individual-level controls for religious affiliation not shown. Standard errors in parentheses. Coefficients are statistically significant at $* p<0.05 ; * * p<0.01$.

Source: Comparative National Elections Project. 
2013). If so, we would find an interactive relationship between human development and religious attendance, such that the impact of human development turned positive among frequent attenders. In the Appendix, we do find a significant interactive relationship between the two variables; however, human development strongly depresses religious politicking even among the most religiously devout.

\section{CONCLUSION}

In the lead-up to the United States' 2006 congressional primary, Pastor Mac Hammond sparked a public outcry and eventual Internal Revenue Service inquiry when he invited evangelical Christian and Republican congressional candidate Michelle Bachmann to speak at his church in Minnesota. From the pulpit, Hammond told his congregation, "We can't publicly endorse as a church — and would not—any candidate, but I can tell you personally that I'm going to vote for Michele Bachmann" (quoted in Putnam and Campbell 2012, 332). In contrast to the controversy Hammond generated is the indifferent response of Mayor Jzef Grochowski of the Polish town of Kulesze Kocielne to clergy politicking on the eve of the 2015 parliamentary elections. While "the priest does not tell people which political party to support ... he advises us to vote for a politician who is a good Catholic, from a party that represents the ideals of the church"-which, he implied, obviously meant voting for the conservative Law and Justice Party (Smith 2015).

Informal social interactions shape electoral behavior across the globe (Zuckerman 2005; Gunther et al. 2015). Nonetheless, this regularity conceals great diversity in the ways social ties affect elections: which ties matter and how they matter. One source of variation relates to religious leaders and activists: some people and places are much more likely to be exposed to religious politicking than others. What accounts for this variation?

Utilizing a cross-national survey incorporating individual- and countrylevel data, we have addressed prominent explanations of religious politicking. Civilizational approaches claiming that some religious groups take to politics as a result of inherent doctrinal positions or immutable cultural traits prove insufficient. Instead, religious politicking is a response to environmental opportunities and constraints. Our findings partially support modernization theorists' predictions. While liberal democracy is statistically insignificant in multivariate analysis, the process of development tends to diminish religion's role in politics. Yet when policymakers 
adopt secular constitutional frameworks, they paradoxically encourage religious politicking. Finally, our results support the argument within the religious competition literature that religious pluralism fosters engagement in politics. And at the individual level, although individuals with more education are less religiously engaged, they are more likely to be targets of religious mobilization and the impact of education is stronger in countries where religious politicking is more common.

Potential limitations to the study revolve around the nature of our country sample and data, including the reliance on individual self-reports. These limitations point toward avenues for further research. To improve measures of the dependent variable, future researchers could develop cross-national surveys of clergy or analyze cross-national data from sermons. Survey experiments could also enable a better understanding of clergy motivations and illuminate how clergy respond to various incentives (Calfano, Michelson, and Oldmixon 2017; Smith 2019). Finally, more narrowly focused studies examining only a single religious group (for instance, Catholics) could facilitate a richer understanding of the impact of context. A final set of questions remains for future research. Does this form of social influence shape election outcomes? Does it matter differently in different times and places? Answering these questions will further illuminate the greatly varying forms of religious socialization around the world.

\section{SUPPLEMENTARY MATERIAL}

The supplementary material for this article can be found at https://doi.org/ $10.1017 / \mathrm{S} 1755048320000644$.

\section{ACKNOWLEDGMENTS}

Thanks to Iván Garzón, Mike Hoffman, Stephen Mockabee, Mark Nieman, Dave Peterson, Guillermo Trejo, Peter W. Wielhouwer, an anonymous reviewer for the Kellogg Institute's Working Paper series, and reviewers of the Politics \& Religion journal for helpful comments on prior drafts of this paper. A prior version of this paper was presented at the 2018 Annual Meeting of the Midwest Political Science Association, and a revision was published as a Kellogg Institute Working Paper. The data used in this paper may be downloaded from the Comparative National Elections Project: https://u.osu.edu/cnep/surveys/surveysthrough-2012/. 


\section{NOTES}

1. Yet another reinterpretation of secularization theory focuses on inequality, rather than development per se. Karakoç and Başkan $(2013,1511)$ argue that inequality "creates a socioeconomic and political context in which people are more likely to support the role of religion in politics." For reasons that we discuss in a later footnote, we are unable to effectively test the impact of inequality on religious politicking in these data; our results are ambiguous with respect to this hypothesis.

2. Question translations vary in minor ways from survey to survey. This represents the text from the 2004 Mozambique survey.

3. HDI is based on three dimensions: healthy lifespan, standard of living, and knowledge. In analysis presented in the Appendix, we also assessed the impact of inequality on religious politicking, using the V-Dem measure of "High Income Inequality" (Coppedge et al. N.d.).

4. No other measure of religiosity is consistently available in our data. We would argue that religious attendance is a particularly important indicator of religiosity for studying elite-mass communication. However, we also recognize that the nature and religious significance of religious attendance varies across traditions. The impact of religious attendance on message reception appears to be slightly, but not statistically significantly, stronger among Christians.

5. Here we present the rates of receiving electoral information among all citizens, not just those belonging to religious organizations or attending houses of worship. In the Appendix we present equivalent figures limited to citizens who belong to religious organizations or attend houses of worship. The country-level distributions are surprisingly consistent across the two measures. This paper relies on the distribution among all citizens, both to reduce selection bias and to substantially increase our sample size, since few citizens attend houses of worship in some countries.

6. In the Appendix, we present a figure depicting country-by-country analysis incorporating other demographic variables, including age, income, and gender. Because these variables are available inconsistently in the various studies, it is impossible to include all of them together in a single pooled model. The effects of these other demographics vary substantially across contexts, yet the overall pattern is of statistical insignificance.

7. In the Appendix, we discuss results including a measure of inequality. The analysis incorporating this measure is hampered by the lack of data from the United States on the measure of religious contact. Though the measure of inequality is statistically significant in analysis excluding the United States; the United States is an important case because it has among the highest religious politicking in our data but moderate levels of inequality in cross-national context. In various analyses using the summary index, the coefficient for the Gini index becomes statistically insignificant.

8. The Appendix discusses results limited to Catholics, enabling us to control for many "civilizational," historical, and religious institutional factors within the tradition. The results are strongly consistent with our broader analysis.

9. One important question relates to whether we have enough variation in levels of democracy among our cases to observe any potential effect of democracy. While our sample is limited to countries with free and fair elections, Table 1 shows substantial variance in our measure of liberal democracy, from Greece and Indonesia at the low end to several European democracies at the high end. Nonetheless, our results should not be extrapolated out of the bounds of our sample, to apply to authoritarian and semi-authoritarian regimes.

10. The Appendix presents correlations among the contextual variables; human development and democracy are highly correlated, as are religious pluralism and secularism.

\section{REFERENCES}

Akdede, Sacit Hadi. 2010. "The Religion and State-Minorities Dataset." Economics Letters 106 (2): 101-104.

Audette, Andre P., and Christopher L. Weaver. 2016. "Filling Pews and Voting Booths: The Role of Politicization in Congregational Growth." Political Research Quarterly 69 (2): 245-257.

Berger, Peter. 1967. The Sacred Canopy. Garden City: Anchor Books.

Berger, Peter. 1979. The Heretical Imperative. New York City: Anchor Books. 
Berger, Peter L. 2012. "Further Thoughts on Religion and Modernity." Society 49 (4): 313-316.

Bolzendahl, Catherine, Landon Schnabel, and Rottem Sagi. 2019. "Religion and Democratic Citizenship: A Multilevel Examination." Politics and Religion 12 (4): 577-605.

Brady, Henry E., Sidney Verba, and Kay Lehman Schlozman. 1995. "Beyond SES: A Resource Model of Political Participation." American Political Science Review 89 (2): 271-294.

Bruce, Steve. 2002. God Is Dead: Secularization in the West. Vol. 3. Oxford: Oxford: Blackwell.

Calfano, Brian, Melissa R. Michelson, and Elizabeth A. Oldmixon. 2017. A Matter of Discretion: The Politics of Catholic Priests in the United States and Ireland. Lanham, MD: Rowman \& Littlefield.

Casanova, José. 2011. "Cosmopolitanism, the Clash of Civilizations and Multiple Modernities." Current Sociology 59 (2): 252-267.

Chaves, Mark. 1994. "Secularization as Declining Religious Authority." Social Forces 72 (3): 749-774.

Clark, Amy. 2007. "Jesse Jackson Endorses Barack Obama.” CBS News, March 29.

Conroy-Krutz, Jeffrey. 2016. "Electoral Campaigns as Learning Opportunities: Lessons From Uganda." African Affairs 115(460):516-540.

Coppedge, Michael, John Gerring, Staffan I. Lindberg, Svend-Erik Skanning, Jan Teorell, David Altman, Frida Andersson, Michael Bernhard, M. Steven Fish, Adam Glynn, Allen Hicken, Carl Henrik Knutsen, Kelly McMann, Valeriya Mechkova, Farhad Miri, Pamela Paxton, Daniel Pemstein, Rachel Sigman, Jeffrey Staton, and Brigitte Zimmerman. N.d. Varieties of Democracy (V-Dem) Project. Vol. V-Dem Codebook v6.

Cruz E Silva, Teresa. 2008 "Evangelicals and Democracy in Mozambique," In Evangelical Christianity and Democracy in Africa, ed. Terence O. Ranger, New York: Oxford University Press.

Da Silva, Fernando 2015. "The Role of the Christian Council of Mozambique in the Colonial War (1964-1974) and in Civil Wars (1977-2014): Christians in Colonial Wars." Studia Historiae Ecclesiasticae 41(1):105-121.

Djupe, Paul A., and Jacob R. Neiheisel. 2019. "Political Mobilization in American Congregations: A Religious Economies Perspective." Politics and Religion 12 (1): 123-152.

Dowd, Robert A. 2015. Christianity, Islam, and Liberal Democracy: Lessons From SubSaharan Africa. New York: Oxford University Press.

Emont, Jon. 2017. "Does the Quran Forbid Electing Christians?" The Atlantic, April 18.

Esquivel, Juan Cruz. 2016. "Religion and Politics in Argentina: Religious Influence on Legislative Decisions on Sexual and Reproductive Rights." Latin American Perspectives 43 (3): 133-143.

Fealy, Greg, and Robin Bush. 2014. "The Political Decline of Traditional Ulama in Indonesia: The State, Umma and Nahdlatul Ulama." Asian Journal of Social Science 42 (5): 536-560.

Finke, Roger, and Laurence R. Iannaccone. 1993. "Supply-Side Explanations for Religious Change." The Annals of the American Academy of Political and Social Science 527 (1): 27-39.

Finke, Roger, and Rodney Stark. 1998. "Religious Choice and Competition." American Sociological Review 63 (5): 761-766.

Fox, Jonathan. 2006. "World Separation of Religion and State Into the 21st Century." Comparative Political Studies 39 (5): 537-569. 
Gaskins, Ben, Matt Golder, and David A. Siegel. 2013. "Religious Participation, Social Conservatism, and Human Development." The Journal of Politics 75 (4): 1125-1141.

Gill, Anthony. 2008. Rendering Unto Caesar: The Catholic Church and the State in Latin America. Chicago: University of Chicago Press.

Goldman, Russell. 2008. "Pastors Challenge Law, Endorse Candidates From Pulpit." ABC News, June 20.

Grzymala-Busse, Anna. 2015. Nations Under God: How Churches Use Moral Authority to Influence Policy. Princeton: Princeton University Press.

Gunther, Richard, Paul A. Beck, Pedro C. Magalhães, and Alejandro Moreno, eds. 2015. Voting in Old and New Democracies. New York: Routledge.

Huntington, Samuel P. 1968. Political Order in Changing Societies. New Haven: Yale University Press.

Huntington, Samuel P. 1993. "The Clash of Civilizations?” Foreign Affairs 527 (1): 22-49.

Iannaccone, Laurence R. 1992. "Religious Markets and the Economics of Religion." Social Compass 39 (1): 123-131. https://doi.org/10.1177/003776892039001012.

Karakoç, Ekrem, and Birol Başkan. 2013. "Religion in Politics: How Does Inequality Affect Public Secularization?" Comparative Political Studies 45 (12): 1510-1541.

Koesel, Karrie. 2014. Religion and Authoritarianism: Cooperation, Conflict, and the Consequences. New York: Cambridge University Press.

Kuru, Ahmet T. 2009. Secularism and State Policies Toward Religion: The United States, France, and Turkey. New York: Cambridge University Press.

Lussier, Danielle N., and M. Steven Fish. 2012. "Indonesia: The Benefits of Civic Engagement." Journal of Democracy 23 (1): 70-84.

Manning, Carrie 2010. "Mozambique's Slide Into One-Party Rule.” Journal of Democracy 21(2):151-165.

McCauley, John F. 2017. The Logic of Ethnic and Religious Conflict in Africa. New York: Cambridge University Press.

Norris, Pippa, and Ronald Inglehart. 2011. Sacred and Secular: Religion and Politics Worldwide. New York: Cambridge University Press.

Pecheny, Mario, Daniel Jones, and Lucía Ariza. 2016. "Sexual Politics and Religious Actors in Argentina." Religion and Gender 6 (2): 205-225.

Pereira, Joo C.G. 2008. Partisan Identification in Africa: An Exploratory Study in Mozambique. Ph.D. Thesis, Cape Town: University of Cape Town.

Philpott, Daniel. 2007. "Explaining the Political Ambivalence of Religion." American Political Science Review 101 (3): 505-525.

Putnam, Robert D., and David E. Campbell. 2012. American Grace: How Religion Divides and Unites Us. New York: Simon and Schuster.

Smith, Alex Duval. 2015. "In Deepest Rural Poland, Politics Is Shaped by Love of Church and Hatred of Brussels." The Guardian, October 24.

Smith, Amy Erica. 2018. "Talking It Out: Political Conversation and Knowledge Gaps in Unequal Urban Contexts." British Journal of Political Science 48 (2): 407-425.

Smith, Amy Erica. 2019. Religion and Brazilian Democracy: Mobilizing the People of God. New York: Cambridge University Press.

Stark, Rodney. 1999. “Secularization, R.I.P.” Sociology of Religion 60 (3): 249-273.

Stark, Rodney, and Roger Finke. 2000. Acts of Faith: Explaining the Human Side of Religion. Berkeley, CA: University of California Press.

Stepan, Alfred C. 2000. "Religion, Democracy, and the 'Twin Tolerations'." Journal of Democracy 11 (4): 37-57.

Stokes, Susan C., Thad Dunning, Marcelo Nazareno, and Valeria Brusco. 2013. Brokers, Voters, and Clientelism: The Puzzle of Distributive Politics. New York: Cambridge University Press. 
Sued, Gabriel. 2007. "Oposición al aborto de los principales candidatos." La Nación. October 23.

Sumaktoyo, Nathanael Gratias, Victor Ottati, and Vinaya Untoro. 2016. "The Paradoxical Religiosity Effect: Religion and Politics in Indonesia and the United States." Politics and Religion 9 (3): 481-507.

Tanuwidjaja, Sunny. 2010. "Political Islam and Islamic Parties in Indonesia: Critically Assessing the Evidence of Islam's Political Decline." Contemporary Southeast Asia: A Journal of International and Strategic Affairs 32 (1): 29-49.

Toft, Monica, Daniel Philpott, and Timothy Shah. 2011. God's Century: Resurgent Religion and Global Politics. New York: W.W. Norton \& Company.

Trejo, Guillermo. 2012. Popular Movements in Autocracies: Religion, Repression, and Indigenous Collective Action in Mexico. Cambridge: Cambridge University Press.

United Nations Development Programme. N.d. Human Development Data, 1990-2015.

Verba, Sidney, Norman H. Nie, and Jae-on Kim. 1978. Participation and Political Equality: A Seven-Nation Comparison. Chicago: University of Chicago Press.

Zaller, John R. 1992. The Nature and Origins of Mass Opinion. New York: Cambridge University Press.

Zuckerman, Alan S. 2005. The Social Logic of Politics: Personal Networks as the Contexts for Political Behavior. Philadelphia: Temple University Press.

Emma Rosenberg is a $\mathrm{PhD}$ candidate in political science at the University of Notre Dame. She studies the intersection of religious and nativist identities in Central Europe, with a focus on political communications.

Amy Erica Smith is an associate professor of political science as well as a Liberal Arts and Sciences Dean's Professor at Iowa State University. In the 2020-22 academic years, she is an Andrew Carnegie Fellow. Her research examines citizenship, democracy, and religion, with a primary focus on Latin America, and especially Brazil. 